\title{
4. ラット遺伝性腎がんからアスベスト・中皮腫診断へ
}

\author{
樋 野 興 夫 \\ 順天堂大学医学部 病理・腫瘍学
}

はじめに

2005 年のノーベル医学生理学賞は「へリコバクタ 一・ピロリ菌の発見と胃炎・胃・十二指腸潰瘍における 役割の解明」であった。筆者の脳裏にすぐ浮かんだの は,「寄生虫による胃がんの発生」の 1926 年のノーベ ル賞と, その時のもう一人の候補者であったが残念な がら幻のノーベル賞に終わった山極勝三郎（1863～ 1930）である.山極勝三郎は若き日（1891〜1894 年） ドイツのウイルヒョウ（1821～1902）に学び, 㷌国後 は「胃癌発生論」(1905 年)を出版し, がん発生に対す る考えをじっくりと温め, 10 年後に「コールタールに よる人工発がん」を我慢強く, 丁寧に仕上げ, 最後に は立派に完成した. 恩師ウイルヒョウの発がんの「刺 激説」を見事に実証した, 日本が世界に誇る病理学者 である。

人工発がんの創始国である日本で,「アスベストによ る中皮腫」の問題が毎日のように新聞, 雑誌に取り上 げられ, テレビ, ラジオで報道されているとはなんと も皮肉なことである.

20 世紀はがんをつくる時代であったが，21 世紀は 「がんを遅らす」研究で世界をリードする時である，発 がんの 3 か条は 1) It is not automatic. 2) It has a process. 3) It takes a time. である (がん化の扇論). がんの予防・治療の介入ができる根拠はここにあると 考えられる.

本稿では「疾患モデルからヒト発がんの本態解明へ」 をKey wordに, 疾患モデルからヒトへのTranslational researchの実例を示す.

「アスベスト・中皮腫」外来開設

2005 年 6 月の, いわゆる「クボタショック」以来, アスベストを原因とする中皮腫の発症は大きな社会問 題となっている. 国としても様々な対策を立て, 中皮 腫患者の状況把握, アスベスト関連企業従事者や工場 周辺の住民の健康調查などが開始されつつある. 過去
のアスベストの使用状況を考えれば，曝露者数は極め て大きく，今後中皮腫患者の発生増加が眯念されてお り, 比較的リスクの高いグループの検診体制の確立が 急務である.

2005 年 8 月, 順天堂大学の英断を誘い, 全国に先駆 けて「アスベスト・中皮腫外来」が実現されるに至っ た。そもそも，筆者が，「アスベスト・中皮腫外来」に 関与することになったのも全く偶然であった。そもそ も発がん研究者として, (1)炎症（肝炎ウイルス）によ る肝発がん, (2)遺伝による腎発がんをテーマに長年研 究を進めてきた.今回の「アスベスト・中皮腫外来」 のきっかけは, 後者の研究から 10 年以上前に発見した 遺伝子である. その後, その遺伝子産物が, 中皮細胞 に特異的に発現し,さらに血中に分泌されるという性 質を有していることが判明し，侏免疫生物研究所と共 同で血中蛋白量の測定法を地道に開発していたからで ある。

\section{環境発がんの見直し}

そもそも污染された環境を原因とする「がん」に冒 されることを専門的には「環境発がん」という。古く は 1775 年, イギリスの外科医ポットの「煤による刺激 によって煙突掃除人に陰襄がんが発生する」という報 告に始まる。産業革命に始まる工業化によって我々の 生活に入り込んだものだ.「文明の凶器」といわれる所 以である. 本人の意思と関係なく接触を強いられたこ とに悲劇性がある. 現在のアスベスト問題でも同様で ある。

これから求められることは, リスク評価に加えてリ スクマネージメント, コミュニケーションであろう. どのくらいの期間, どのくらいの量に曝露されれば「が ん」になる危険があるのか実は曖昧である. 発がんに 長い期間（20～30 年）要することも曖昧さの一因であ る. 予見能力についてプロの何たるかが問われる時で もある。

第 23 回日本疾患モデル学会シンポジウム「疾患モデルからヒト発がんの本態解明へ」講演記録 


\section{アスベストの健康被害}

アスベスト（石綿）は，天然の緎維状のケイ酸鉱物 で, 北米特にカナダ・ケベック州に埋蔵量が多く，そ の代表的産物として白石綿(温石綿)，青石綿あるいは 茶石綿がよく知られている。この石綿は絶緑性や不燃 性に優れているため断熱剤や塗料などの建築資材, 織 物，ブレーキライニングやパッドなどに幅広く利用さ れ，古くはエジプトのミイラを包む布としても使用さ れていた。我が国においても竹取物語に石綿に関する 記載がみられ，また，平賀源内は石綿を布にして幕府 に献上したとのことである。

アスベストによる健康被害については, 1959 年に欧 州で悪性中皮腫との関係が報告されたのを手始めに， 1960 年に南アフリカのアスベスト鉱山周辺の住民に 中皮腫の発生がみられ職業暴露による影響が懸念され た. 1971 年には WHO の下部組織である国際がん研究 機関 (IARC) の専門会議でアスベストの発がん性が指 摘され，以降アスベスト（特に青石綿と茶石綿）の使 用が欧米各国で規制あるいは禁止されるようになっ た。我が国ではアスベストの輸入量がピークを迎えた 1970 年代に建築現場での吹き付けアスベストの使用 が禁止され, 1980 年代には全国各地の小中学校の建物 あるいは実験機材（アスベスト金網）へのアスベスト の使用が問題となり，その後にアスベスト金網は姿を 消した。

特に 1995 年の阪神大震災で倒壊した建物の解体工 事でアスベストの飛散が問題視されたが，現在におい ても建築資材にアスベストを使用した古い公共施設や 家屋の解体処理に同様な問題が発生し，ヒト健康影響 への懸念は未だに払拭されていない。

中皮腫は胸膜や腹膜にできる悪性腫崵の 1 種で，七 トではアスベストを肺内に吸引することにより発生す ることが指摘されており，“Asbestoma”と呼んでも よい腫瘍性疾患である（ラットでは，自然発症の中皮 腫がある).しかし，肺内に吸引されたアスベストがど のような機序で肺外壁の胸膜あるいは腹膜に腫瑒を誘 発するのかについては謎が多い。アスベストにより誘 発される中皮腫は，暴露から発症までの潜伏期間が 35 年前後と長く, 一旦発症したら治療が難しいため早期 発見・早期治療が重要である。しかし，現在一般に用 いられている診断法は, 断層撮影 (CT スキャン) ある いは生検材料による診断で, 検出された時には既に進 行していることが多い.

\section{Translational research $の$ 実例}

筆者らは，上述のように遺伝性ラット腎発がんの進 行過程で高発現してくる遺伝子 $(\mathrm{Erc})$ を以前に発見し た。この Erc 遺伝子産物は，血中に分泌され，遺伝性 ラット腎がんの血液診断に使用できることを，明らか にした．正常ではラットも，七トも胸膜や腹膜の中皮 に存在することから，中皮腫になれば同蛋白が増加し， ヒト悪性中皮腫においては腫瘍マーカーになりうるこ とが予測された。そこで, ELISA 系を(株)免疫生物研 究所と共同で中皮腫を血液で診断するキットの開発と を行った。

ERC は別名 Mesothelin/MPF の総称でもあり, 肺，心蔵，胃腸，肝臓などの臓器を包む胸膜・腹膜・ 心膜などの膜の表面をおおうている中皮細胞や，中皮 腫, 卵巣癌, などのがん細胞が作り出す, 糖タンパク 質である。この ERC タンパク質は，全長 622 アミノ 酸, 分子量が約 $71 \mathrm{kDa}$ からなる GPI アンカー型膜夕 ンパク質として発現した後, 分解酵素によって, 31 $\mathrm{kDa}$ と $40 \mathrm{kDa}$ の断片に分解されることが知られてい る. 切断された $40 \mathrm{kDa}$ の 末側領域はその $\mathrm{C}$ 末端に GPI アンカー領域を含むことから細胞膜に結合した 形で残るが,一方, $\mathrm{N}$ 末側の $31 \mathrm{kDa}$ 断片は可溶性タン パク質として細胞外に分泌される。我々は，この 31 $\mathrm{kDa}$ 断片に着目し，これを検出する ELISA 測定キッ トの開発を行った。すなわち, $31 \mathrm{kDa}$ 断片に結合する 2 種類の抗体を作製し，いわゆるサンドイッチ ELISA 法に基づいた測定キットを開発した。これは，一方の 抗体を試験用マイクロプレートに固定化し，そこへ患 者血清などの検体を反応させ，結合した標的分子 （ERC）をさらにもう一方の抗体で挟み込むようにし て検出する方法である。

本キットを用いた測定によって，がん由来培養細胞 を用いた実験系や健常人血液中においても，一定量の $\mathrm{ERC}$ が存在することが明らかになった，さらに，中皮 腫と診断された患者血清においては，その存在量が高 まることも見いだされてきている．今後の精査によっ て，本キットでの測定により，中皮腫の進行状況をよ り早期に診断することが可能になると考える。このキ ットは，アスベスト被害の危険性を有するヒトを対象 にしたスクリーニングにも有効であると考えられ，今 後は症例を重ね精查することにより中皮腫の早期発見 に繋げたい. 


\section{研究型検診の推進}

アスベストは，建材をはじめとして，広く一般的に 使用されていた。そのため，アスベストによる健康障 害を発症しないかとの強い不安を, 多くの国民が感じ ている. 国民の健康障害に関する重要課題解決型研究 として,アスベスト・中皮腫の克服に向けた総合戦略 は「目下の急務」であろう.

まず診療体制の充実が挙げられる．アスベスト暴露 から中皮腫の発生までの長い潜伏期間（35 年前後）を 考慮し, 被爆者の継続的追跡調査を行う体制整備が不 可欠であり，また，診断から治療まで総合的に引き受 ける診療機関の全国的ネットワークが必要であろう。

簡便で繰り返し検査が可能な中皮腫の血液測定キッ 卜は，膨大な数にのほるアスベスト曝露群に対する 1 次スクリーニング法として有用である。この1次スク リーニング法に高精度化した診断を 2 次スクリーニン グとして加えれば, 膨大な数のアスベスト曝露群から 早期の中皮腫患者を効率的・高精度に発見する総合的 中皮腫早期診断システムを構築することが可能とな り，アスベスト中皮腫の克服という国家的要請に対す る学際的回答として,そのインパクトは計り知れない.
さらに，これを国内および今後，日本と同様に中皮腫 患者の急増が懸念される東南アジアの国々に対して普 及させ, 当該分野の国際貢献を図られる.

おわりに

アスベストによる中皮腫の発がんの仕組みがわかれ ば，根治に難しい中皮腫の治療法に光明が見えてくる はずである．この機を逃さず環境発がんの問題に国家 事業として社会全体で真剣に取り組まないと,「将来を 示す不吉の兆候が空にある」如く, 今後第 2 あるいは 第 3 のアスベスト問題が必ず起きるであろう. 次は, ナノ粒子であろうか？ 研究者も傍観者にならずに 「いばらの道にも」知恵を絞り出す時である.

「闇に飛び立つミネルバの臬」(後追い) でなく， 「朝方に舞い飛ばんとする大志」ある「ミネルバの臬」 に期待したいものである.

筆者は, 山極勝三郎（1863～1930） と吉田富三 (1903〜1973), Knudson(1922〜)の学問の継承を「志」 として「疾患モデル」を用いた研究に従事している。 山極勝三郎, 吉田富三, Knudson はまさに「大観し, 要約して, 真理のある方向を示し, 混沌の中に一筋の 正路を見いだす」がん哲学者でもある. 